\title{
Estado y violencia en el medio rural de México y Brasil*
}

\author{
Jesús Ruvalcaba Mercado
}

Los objetivos de estas líneas son dos: mostrar que hasta hoy la represión es una característica constante pero no inherente a las formas de gobierno que imperan en México y Brasil y probar que los motivos actuales de la violencia en los dos países tienen que ver más con los privilegios e intereses de las clases dominantes que con las diferencias formales o el tipo de colonización por el que atravesó cada uno de estos países. Para lograr estos objetivos, el autor revisa a grandes rasgos los motivos más constantes y generales por los que se ha recurrido a la represión en las últimas décadas en uno y otro lugar. El esbozo, sin pretensión de historia, comprende las tendencias más frecuentes y recientes por las que ambos Estados han usado de la violencia en el medio rural.

There are two aims to this article: to show that up to now repression is a constant but not inherent characteristic to the forms of government prevailing in Mexico and Brazil, and prove that the current motives for violence in both countries are more related to the privileges and interests of the dominant classes than to the formal differences or the type of colonization each of these countries experienced. To achieve these aims the author makes a superficial review of the more constant and general motives for which both countries have resorted to violence in recent decades. The outline, with no historical pretension, includes the most frequent and recent trends for which both States have used violence in the rural sphere.

JESÚS RUVALCABA MERCADO: CIESAS.

Desacatos, núm. 14, primavera-verano 2004, pp. 169-186.

\footnotetext{
* Esta reflexión se basa en trabajo de campo y varias noticias acerca de la Huasteca y en material bibliográfico sobre ambos países. Luego de escribir una versión previa, se me pidió actualizar los datos para su publicación. Añadí cuestiones que me parecieron relevantes para la argumentación del trabajo. Los escritos de los últimos tiempos referentes a Brasil los obtuve de la red electrónica mundial; los de México, de mi propia experiencia y de los diarios nacionales. Agradezco al doctor Pablo Hernández sus comentarios y la lectura crítica que hizo desde el punto de vista médico.
} 


\section{CONSIDERACIONES INICIALES}

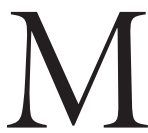

éxico y Brasil son países con cierto liderazgo en el ámbito latinoamericano. Esta influencia se debe a su capacidad industrial, a la infraestructura y los servicios instalados, a la riqueza de sus recursos naturales, a su extensión geográfica y al tamaño de su población. México se encuentra entre los 15 países más extensos y entre los 12 más poblados del mundo (Warman, 2003: 111), mientras que Brasil se ubica entre los cinco más grandes y más poblados del orbe y como el más poblado y más extenso de Latinoamérica. Para la propiedad rural el tamaño del país tiene repercusiones inmediatas pues mientras en Brasil el minifundio se define como la propiedad menor a 20 hectáreas, en México es el menor de cinco hectáreas, que entre los campesinos es, cada vez más, tan sólo una aspiración. Al mismo tiempo las dos naciones son las más endeudadas de América Latina y la desigualdad en ellas existente entre la cúspide y la base de la pirámide social se cuenta entre las mayores del planeta, además de que crece día con día. Actualmente, en cada uno de estos países viven más de 53 millones de personas en la pobreza; para dar una idea de la desigualdad imperante, baste decir que ambas naciones cuentan con algunos de los hombres más ricos del continente mientras la mayor parte de la población sobrevive con menos de dos dólares al día. Unas cuantas familias que conforman la oligarquía regional y nacional controlan y disfrutan la riqueza que se produce socialmente. Esta situación se agrava y adquiere tonos dramáticos en el campo, donde existen terratenientes, latifundistas, fazendeiros y caciques que ejercen un férreo control político y social sobre la población campesina e indígena con la anuencia de los gobernantes y el apoyo logístico del Estado. A cambio, ellos apoyan al gobierno en turno, frenan las demandas campesinas, extraen excedente y llevan a cabo el despojo agrario y la expoliación de los recursos.

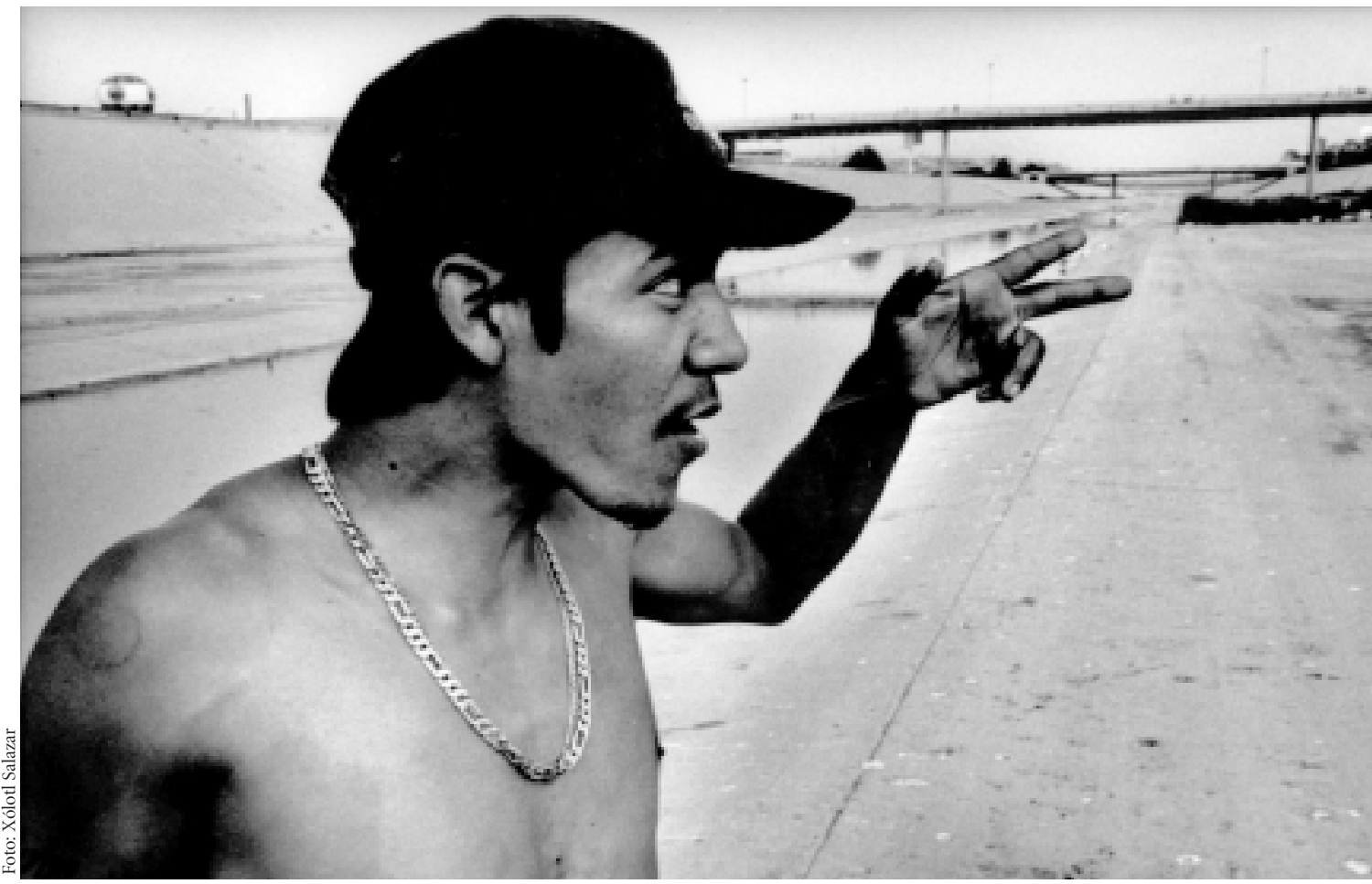

El Chonte en El Bordo; Tijuana, 2000. 
En los dos países, la proporción entre la población rural y la urbana cambió a partir de la segunda mitad del siglo XX y sus sistemas políticos pasaron por nuevas etapas consideradas más democráticas con respecto a los regímenes del pasado. En las elecciones presidenciales mexicanas del año 2000, luego de 75 años de monopolio político de un solo partido (el Partido Revolucionario Institucional, PRI) triunfó un partido de oposición (Partido Acción Nacional, PAN), mientras que en Brasil, en el año 2001 llegó a la presidencia el Partido del Trabajo (PT), luego de un periodo de transición y varios gobiernos militares. No obstante, la desigualdad económica y la injusticia social -que se traducen en la opulencia de unos cuantos y la miseria de la inmensa mayoría — siguen siendo parte de sus grandes problemas nacionales, tanto entre la población rural como entre las clases sociales mayoritarias que habitan las ciudades. En éstas se concentran la industria, la principal actividad económica y el poder político, condiciones que las convierten en polos de atracción para la migración desde el campo.

\section{EL PROBLEMA DE LA VIOLENCIA}

La violencia, esa lacra social, no se explica si se analiza aislada pues forma parte de un problema mayor y más complejo. La violencia desempeña un papel fundamental como mecanismo para mantener el orden social favorable a las clases dominantes y sólo se entiende cuando se ubica dentro de un marco mayor que incluye: 1) la explotación económica de las clases trabajadoras y la expoliación de los recursos naturales, mismas que se conforman como un proceso histórico y global; 2) la opresión social que también comprende la discriminación, el racismo y la descalificación de las expresiones culturales de los dominados y 3) la represión en contra de los dominados (en general campesinos, indígenas, obreros, menores, colonos y mujeres) cuando protestan por la explotación de que son objeto o por el respeto a sus derechos individuales y colectivos. Los tres factores son parte pero cada uno comprende diferentes esferas del problema; en la práctica no se echa mano de ellos de manera indiscriminada. El proceso es uno pero sus etapas y circunstancias son diferentes.
1) La explotación tanto de los recursos naturales como de la mano de obra es una relación económica; en ella se basa la acumulación y el despilfarro de la riqueza por las clases gobernantes, es el pilar principal de la desigualdad social. Asimismo, es el aspecto más amplio del problema teórico. En la vida cotidiana se ejerce a través de mecanismos que se consideran legales o parte de los usos y costumbres. Es decir, la explotación constituye la trama social y a la vez proporciona la estrategia operativa de la interacción entre las clases dominantes y dominadas. La discriminación, el racismo y la descalificación cultural, por separado o todos juntos, son los factores estructurales que aportan $-\mathrm{y}$ refuerzan — la justificación ideológica para explotar a los indígenas y campesinos. Por su parte, la violencia se utiliza para sustentar, reforzar y mantener la explotación cuando los mecanismos económicos e ideológicos son insuficientes o han agotado su eficacia.

La explotación económica en México y Brasil comprende varios mecanismos. ${ }^{1}$ Los tres más comunes son: a) la cotización de los productos y el trabajo de campesinos e indígenas por debajo de su costo social, b) el sobreprecio de los productos y servicios del sector industrial, y c) la apropiación no remunerada de los recursos naturales ajenos. Juntos propician la transferencia de excedente económico que capitalizan para su beneficio las clases dominantes regionales y nacionales.

a) Pagar los productos campesinos o indígenas por debajo de su valor real se hace posible para los compradores porque los precios se fijan en el ámbito nacional y porque regionalmente se aprovecha el carácter estacional de la producción de los alimentos básicos y el nivel de pobreza en que viven los indígenas y campesinos en ambos países. En general, las artesanías y mercancías que venden indígenas y campesinos se abaratan cuando escasean los alimentos básicos, al mismo tiempo que se especula con lo necesario para su alimentación. Y cuando las cosechas abundan, los alimentos básicos producidos por los campesinos e

\footnotetext{
${ }^{1}$ Desarrollé estos puntos más ampliamente en otro escrito (Ruvalcaba, 2002). Por lo mismo, aquí sólo resaltaré lo más importante del asunto.
} 
indígenas se abaratan y se acaparan para encarecerlos otra vez cuando comienzan a escasear. Estas prácticas se ejercen de manera legal pero injusta a través del sistema mercantil (acaparamiento comercial, salario mínimo, precios bajos a los productos campesinos). En México todavía se pueden encontrar otras prácticas como el rescate o las atajadoras, que son acciones muy cercanas al despojo mismo. ${ }^{2}$ Por lo demás, en ambos países existen todavía haciendas y plantaciones en las que se mantiene a la mano de obra en condiciones de semiesclavitud o como peones acasillados.

b) El segundo mecanismo por el cual se extrae valor a los productores primarios es el de venderles o cobrarles las mercancías producidas por los países industrializados o por el sector industrial nacional entre dos y diez veces más que su precio corriente en los centros urbanos en los que se fabrican. Este sobreprecio es diferente a la tasa de ganancia que lleva en sí cada mercancía y a los gastos de transporte que también se cargan al bolsillo del consumidor. El caso extremo se da en la atención médica donde los servicios se pueden pagar multiplicados por diez. Los caminos por los que llegan las mercancías industriales también son variados; comprenden desde el comercio establecido y los circuitos semanales o tianguis en México, hasta prácticas de endeudamiento a plazos, el bombardeo propagandístico y la entrega a domicilio de los productos, así estén las casas de los consumidores fuera de comunicación automotor.

c) La tercera práctica común es la de pagar salarios a menos de su costo real e incluso por debajo de los salarios mínimos oficiales hasta en la mitad. A la vez, maderas finas, petróleo, minerales, agua y otros recursos natu-

\footnotetext{
${ }^{2}$ El rescate consiste en adelantar pequeñas sumas de dinero a cambio de comprometer la producción agrícola o artesanal; las atajadoras son personas que esperan a los productores indígenas a la orilla de las ciudades los días de mercado para arrebatarles sus mercancías a cambio de algunas monedas. Warman menciona que estas prácticas y otras parecidas se han erradicado (2003: 84). No es el caso en la Huasteca en donde hasta hace muy poco se practicaron o se han sustituido por otras parecidas. El mismo autor señala que: "Hay nuevas oportunidades y espacios para los indígenas pero persiste una frontera que condena a los indios a la pobreza y a la discriminación" (idem: 84).
}

rales que existen en las tierras de grupos indígenas y campesinos se expropian o se explotan sin reportarles beneficio alguno. Fazendeiros, caciques y latifundistas se valen de diversas argucias para no pagar a sus trabajadores o para expoliar los recursos; a veces, se les obliga a asistir por coerción y se les paga con aguardiente; a los niños, mujeres y ancianos se les paga por mitad. También se apropian de los recursos por la fuerza o bajo pretextos legales como el llamado "beneficio de la nación”. Hasta hace poco (y no dudo que todavía en algunas partes de la Huasteca) en México era común la extorsión, el cohecho o la amenaza contra las autoridades indígenas para que a su vez presionaran u obligaran a la comunidad a que el trabajo comunitario semanal, tequio, se hiciera en tierras de los latifundistas. Además, monopolizan el comercio de productos necesarios para la vida religiosa y el sistema de creencias de las comunidades, tan caras a los pueblos indígenas.

Las tres anteriores son las prácticas económicas más comunes que conforman el cambio desigual entre la oligarquía regional y los productores rurales. Todas son consideradas normales y tienen un sustento legal. Este hecho impide que las agrupaciones de los productores primarios tengan éxito en su desmantelamiento. Pero dado que los campesinos diagnostican con toda claridad por dónde se fuga la riqueza que generan, ha habido intentos en ambos países para romper esos círculos viciosos a través de cooperativas tanto de producción como de consumo con diversos grados de eficacia. Los resultados de tales intentos para Brasil se pueden consultar en R. Cardoso (1987), Pereira (2003), Perz (2000), Veltmeyer y Petras (2002). Baste aquí decir que cuando las organizaciones campesinas tienen éxito y logran enjuiciar al sistema de poder establecido, los argumentos que se esgrimen para reprimirlas parecen haber sido sacados del mismo manual: las acusan de acopio de armas y de preparar y mantener campos de entrenamiento para la guerrilla (Sallinger-McBride y Roberts, 1998, en el caso de Brasil y numerosos testimonios reportados en la prensa nacional para el caso de México. Por ejemplo, La Jornada, 2 de septiembre de 1994; La Jornada, 13 de diciembre de 1995 y Crónica, 18 de julio de 1996). 


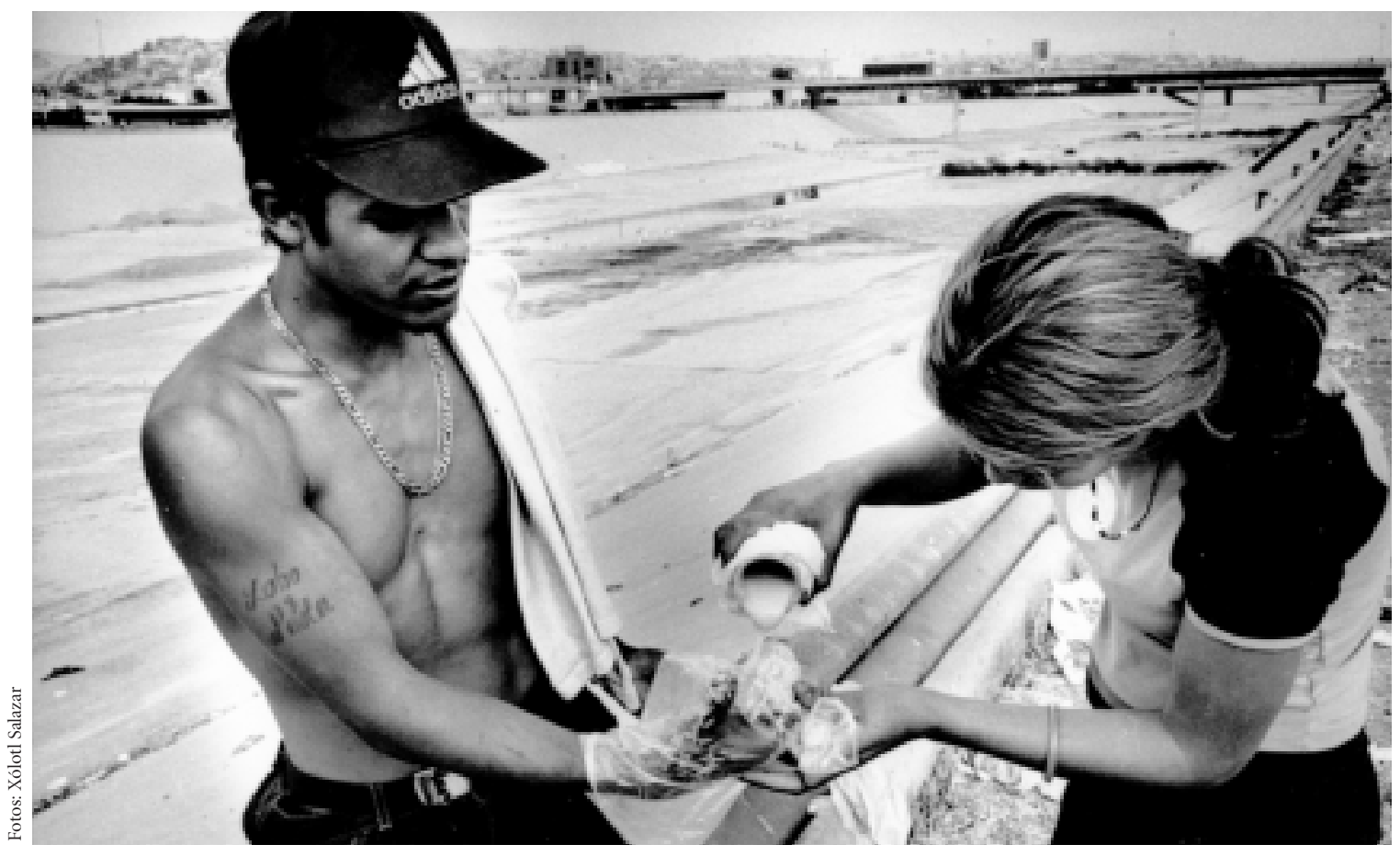

Con el frasco de chemo; El Bordo, Tijuana, 2000.

2) La opresión es una relación sociocultural que se funda en la discriminación y en la descalificación del idioma, la religión, las costumbres, las creencias del grupo dominado, en suma, se trata de fortalecer o justificar el despojo de los recursos naturales y el control político del grupo que los posee. Si la dominación política requiere de una base económica, los componentes de la opresión tienden hacia la justificación de la explotación. Para quienes asumen esta posición, el indígena carece de historia, su cultura es arcaica o primitiva, su lengua no se puede escribir, su agricultura es atrasada y depredadora, su religión es propia de paganos e idólatras, su lógica de producción y mercadeo es caótica y primitiva, son tontos o flojos y, por consiguiente, no son sujetos de su propio destino. Es decir, requieren de un tutor. $Y$ ¿quién mejor para asumir ese papel que los herederos del mundo del conquistador, del encomendero colonial, del plantador liberal o del hacendado conservador, del empresario neoliberal, poseedores de la cultura occidental, que se constituyen al mismo tiempo en los usurpadores de la historia

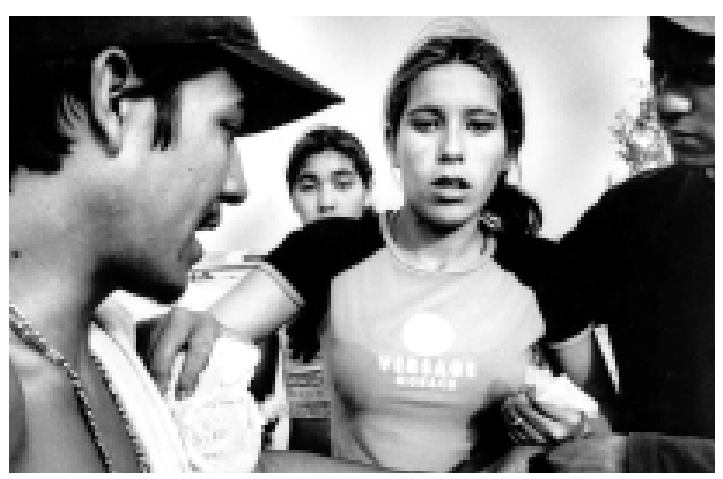

El Chonte, Gabriela, la Morena y el Gato se disputan el frasco de chemo; El Bordo, Tijuana, 2000.

indígena? De allí que en ambos países se haya trabajado tanto para incorporar a los indios al sistema para que dejen de ser indígenas pero no marginados.

En México y Brasil los artificios más importantes por los que funciona la opresión sociocultural y el dominio político, que sirven de refuerzo a la explotación económica son cuatro: 
a) La marginación social. Los 21 jefes de Estado de los países iberoamericanos se han reunido en varias ocasiones con el fin de buscar soluciones conjuntas a los problemas por los que atraviesa América Latina. En las declaraciones que firmaron y avalaron todos ellos en 1991, en la primera Cumbre Latinoamericana, entre una veintena de puntos, en el número 8 de la primera reunión reconocieron: “...la inmensa contribución de los pueblos indígenas al desarrollo y pluralidad de nuestras sociedades y... [reiteraron el] compromiso con su bienestar económico y social, así como la obligación de respetar sus derechos y su identidad cultural" ( $L a$ Jornada, 21 de julio de 1991).

Trece años después, estos propósitos no pasan de ser meros enunciados pues los acontecimientos diarios desmienten cualquier afirmación en contrario. A pesar del reconocimiento oficial de su existencia, en México y Brasil, firmantes por supuesto de esa carta, a los pueblos indígenas como grupos con una cultura propia se les excluye de la toma de decisiones, se les margi- na de los beneficios de educación y salud, se les afecta en sus derechos básicos. Es decir, se les ignora como ciudadanos de sus propias tierras sobre las que tienen derechos ancestrales. Del relativo proteccionismo paternalista en que los mantuvo el régimen colonial pasaron a la categoría civil de marginados del reparto social de la riqueza nacional que les impusieron sucesivamente los gobiernos independentistas, militares, neoliberales y ahora los "gobiernos del cambio". En las regiones indígenas, la marginación adquiere visos de genocidio, palabra fuerte pero no alejada de la verdad cuando se revisan los índices de mortalidad infantil, los grados de desnutrición, el desarrollo físico y las enfermedades más comunes por los que se muere allí. El hecho de que el cólera, la tuberculosis y otras enfermedades que se creían erradicadas desde el siglo pasado fustiguen con mayor virulencia a los pueblos indios y mestizos descendientes de ellos en todos los países de América en los que se presentan como epidemia es el testimonio más contundente al respecto.

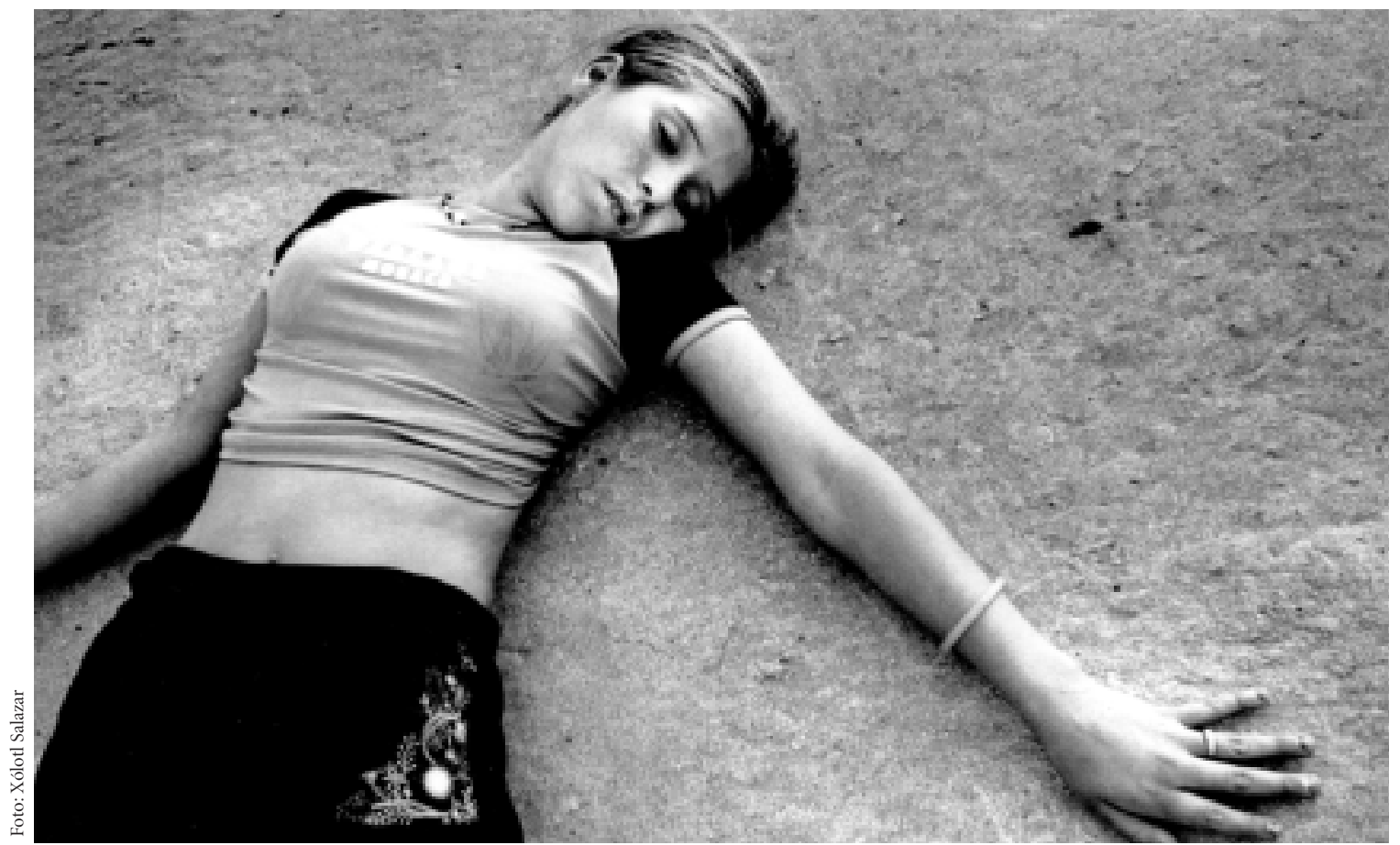

Gabriela en sobredosis; El Bordo, Tijuana, 2000. 
b) La discriminación y el racismo en contra de los grupos indígenas se consideran como algo normal y son parte de la vida cotidiana. Además de atrasados, extraños o salvajes se les cataloga como flojos, sucios, indolentes y borrachos. En las regiones indias, dentro del núcleo familiar, el estereotipo se les inculca con tal fuerza a los niños mestizos que cuando son adolescentes hacen objeto de burla a los indígenas y piensan que son sus sirvientes naturales. Los múltiples crímenes en su contra no se consideran homicidios y no causan mayor conflicto de conciencia que matar a un ser irracional. Otras formas de discriminación incluyen la descalificación acrítica y etnocéntrica del conocimiento y de los rasgos culturales que dan identidad a los grupos indígenas. Para los mestizos de las zonas indias sólo existen los de razón, que por supuesto son ellos, y los indios o irracionales.

c) La educación vigente tiende a eliminar el uso de las lenguas indoamericanas y a inculcar los valores de la cultura occidental como los más altos en la escala sociocultural. Sólo en las declaraciones se contemplan políticas para apoyar la cultura indígena. Cuando se emplean las lenguas o los conocimientos indios es con el fin de lucrar, aculturar o comercializar con ellos pero no de fortalecerlos. Experimentos como las radiodifusoras comunitarias en las zonas indias son apenas intentos que aún no tienen repercusión y falta tiempo para evaluar sus efectos verdaderos; en general se les niegan permisos, apoyos y autonomía. Aspectos como la religión o el sistema de creencias indígenas son objeto de manipulación para disminuir el potencial revolucionario de la comunidad cuando su población se aglutina en torno a ellas. La excepción en ambos países ha sido la tendencia de la teología de la liberación dentro de la Iglesia católica, con la que se relacionó la creación o el fortalecimiento del Movimiento de los Trabajadores sin Tierra en Brasil (Movimento dos Trabalhadores Rurais Sem Terra, MST) y la aparición del Ejército Zapatista de Liberación $\mathrm{Na}$ cional (EZLN) en Chiapas.

d) Las relaciones entre mestizos e indios son racistas; entre éstas se deben incluir las de tipo paternalista que es una forma más sutil pero igual de perniciosa. En estas relaciones no influye la riqueza de cada uno. Bien puede ser que el indígena tenga más recursos que el mestizo y, con todo, el mestizo trata al indígena de tú, no le habla por su nombre de pila sino con algún genérico despectivo y utiliza siempre un tono autoritario. Además de establecer relaciones asimétricas de parentesco ritual, los caciques, fazendeiros y terratenientes se sienten dueños de las tierras y vidas de los indios, de manera que hasta épocas recientes exigían el derecho de pernada. En sus feudos, la voluntad del cacique es ley. A veces se requería del permiso expreso para salir o entrar no sólo de la propiedad particular sino de todo el territorio que controlaba el terrateniente. $\mathrm{Mu}$ chos indígenas han muerto en el intento cuando se dirigían o regresaban de gestionar trámites agrarios, de una escuela, del camino, etcétera.

A través de las relaciones patrón-cliente, los caciques aseguran la lealtad de los campesinos pobres e indígenas: apadrinan niños, prestan dinero, hacen pequeños favores, utilizan el sistema de castigos y recompensas de manera discriminada y establecen compadrazgos con aquéllos que tienen cierta influencia dentro de las comunidades. Para los indígenas, este tipo de relaciones representa la posibilidad de poder acudir a alguien en un caso de urgencia o un apoyo en el mundo de los mestizos. De hecho, los caciques han sido intermediarios entre el mundo indígena y la sociedad nacional, aunque en años recientes las organizaciones campesinas e indígenas independientes también disputan ese papel.

3) La represión, esto es, el conjunto de actos físicos que conforman la violencia, es una relación cuyas raíces se encuentran en la esfera de lo económico, de lo político y en el ámbito de la justicia social pero sus manifestaciones se hacen patentes en lo corporal, en lo físico. Las medidas violentas más frecuentes en contra de los pueblos indios han sido el genocidio y el exterminio indirecto. A través de pistoleros, aunque a veces se recurra a los cuerpos del Estado, el genocidio comprende asesinatos, masacres, violación de mujeres, cercos militares, policiacos o armados a los poblados indígenas, guerras de exterminio e introducción de enfermedades para las cuales no tienen defensas técnicas ni inmunológicas los pueblos ameri- 
canos. El recuento parecido de las acciones del Estado en contra de los campesinos que querían recuperar tierra en Brasil que presentan Sallinger-McBride y Roberts (1998) con lo que sucedió en la Huasteca en las décadas de 1970 y 1980 no es una casualidad sino una semejanza que habla de la naturaleza del Estado en ambos países. El exterminio indirecto, por su parte, atenta en contra de la base material de la subsistencia del grupo y se materializa a través del despojo agrario y de sus recursos naturales, de la evangelización, del confinamiento en reservaciones o tierras inadecuadas para su subsistencia y desarrollo, en condiciones de miseria e insalubridad que provocan la muerte de varios miles de sus integrantes al año por enfermedades curables y de desnutrición.

\section{Los casos}

Las condiciones en que viven y se mantiene a los campesinos y a los pueblos indígenas se ocultan o se minimizan en ambos países, por lo que es una idea común dentro y fuera que debido a las características del sistema gubernamental, las dos naciones gozan de sistemas democráticos que si bien no acabados, al menos preservan cierta estabilidad política que permite el libre juego del mercado político y un equilibrio entre las diversas fuerzas sociales que las componen. En México se afirma que a pesar, o quizá por lo mismo, del monopartidismo que imperó hasta fines de 1980, la violencia ha sido un recurso ocasional, esporádico, usado en casos extremos cuando la inestabilidad ha amenazado a la nación, igual que en Brasil, a través de unos pocos individuos organizados en "grupúsculos, pandillas o bandas", cuyos objetivos obedecen a (nunca se sabe qué son) oscuros intereses. Se da por sentado el que esos intereses van en contra de otra entidad abstracta, nebulosa: la patria, la democracia, la seguridad nacional, la libertad o el orden establecido, abstracciones que empañan el análisis del problema entre la mayoría de la población y no dejan lugar al cuestionamiento de los críticos hacia el Estado.

En cuanto a México, este lugar común tiene una base de verdad sobre la cual se trata de fundamentar como verdadera la proposición usada para montar una imagen pública de paz social, de apertura democrática y de apoyo a las comunidades indígenas, producto de un modelo económico desarrollista que analistas nacionales y extranjeros han creído ser cierto, pero que los acontecimientos de Chiapas y otras regiones indias han puesto al descubierto. La base cierta de la cuestión es que dentro de Latinoamérica, México es el único país que no ha sufrido golpes militares en los últimos 75 años, problema que ha sido una plaga en los demás países de esta parte del continente. Sin embargo, la paz social con justicia, aparejada al respeto por los derechos humanos, individuales y colectivos, brilla por su ausencia. Por ejemplo, respecto a las contiendas electorales, Pinchetti prueba en dos breves artículos (La Jornada, 16 y 17 de diciembre de 1990), que el avance de la democracia ha sido mucho más burlado en México que en el resto de los países del continente. Para el caso de Brasil, se considera que la reforma agraria promovida por el presidente Fernando Henrique Cardoso (1995-2002) rompió con la tendencia histórica y la política agraria de los gobiernos anteriores que favorecieron la concentración de las tierras en pocas manos. Esta reforma se juzgó como "quizá la más grande que se haya realizado en una atmósfera de estabilidad democrática, con respeto a las instituciones" (Pereira, 2003) ya que, según los datos oficiales, se distribuyeron alrededor de 20 millones de hectáreas entre unas 287000 familias sin tierra. Con todo, las cifras se contradijeron y varios analistas, entre ellos Pereira, señala que en el campo no hubo un verdadero rompimiento ni la reforma agraria tuvo el efecto pregonado por el gobierno, aunque en otros aspectos, como la estabilidad económica nacional, hubo verdaderos avances (Pereira, 2003).

Por otro lado, en México, por mandato constitucional, no se permite la reelección en los puestos de elección popular. Con base en esta prohibición se afirma que el sistema mexicano tiene sus propios métodos de autocorrección: cada nuevo presidente mejora los aspectos más exagerados del precedente (Hirshman, 1987: 82) y vuelve el sistema a su equilibrio. La forma de considerar estas tendencias como una nivelación es importante porque de allí se deducen dos conclusiones falsas: a) Sin golpes militares y sin la permanencia en el poder de la misma persona ni equipo de gobernantes, el sistema gubernamen- 


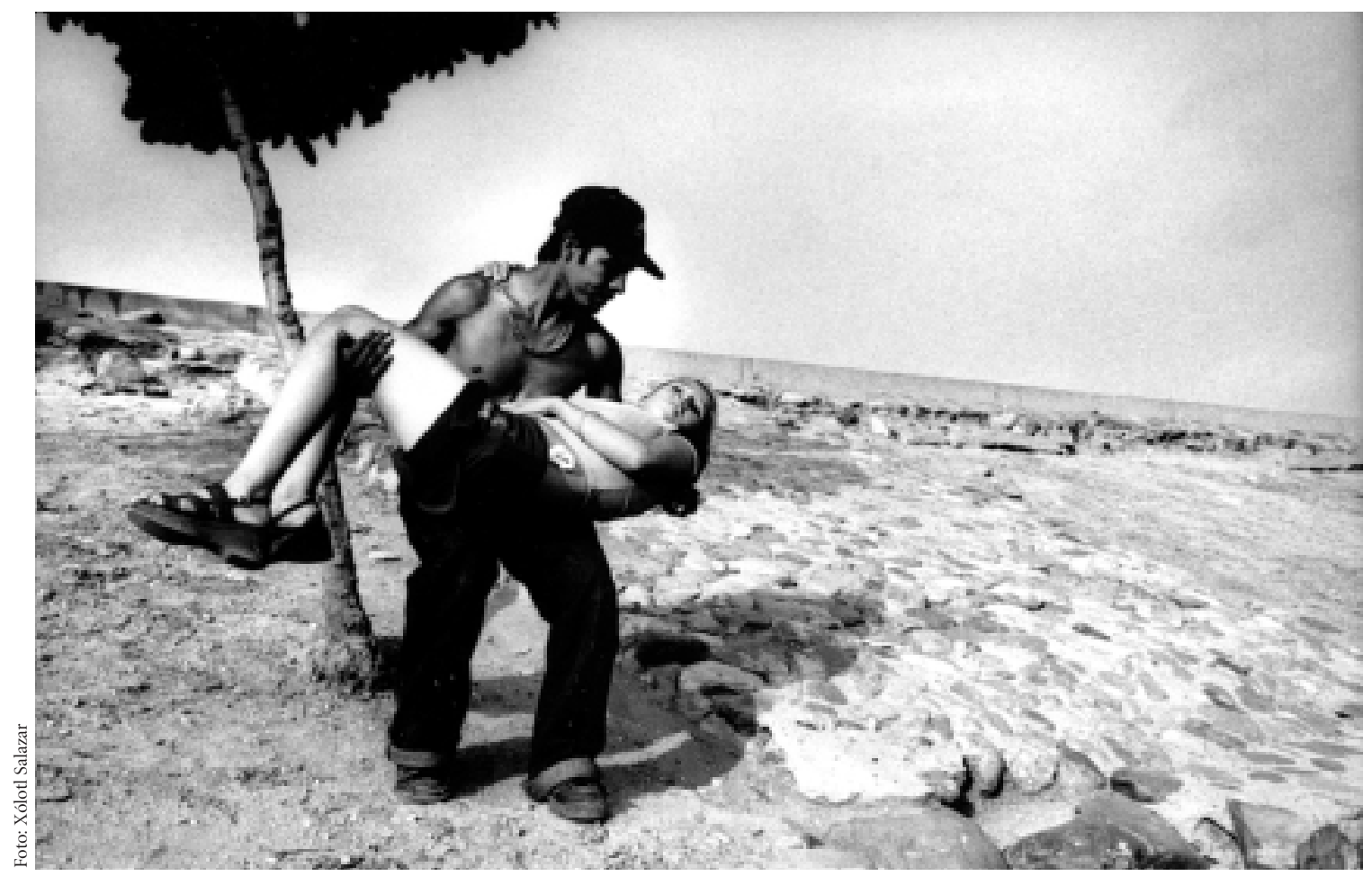

El Chonte auxilia a Gabriela; El Bordo, Tijuana, 2000.

tal mexicano sustenta una cierta apertura para los diversos grupos sociales existentes en la arena política nacional, dentro de la cual los indios gozan de los mismos derechos que el resto de fuerzas sociales.

Por ende, y esta segunda conclusión errada bajo cualquier punto de vista es la que más importa, se sostiene desde diferentes enfoques que, b) Por el relevo de mandos obligado, el Estado mexicano no requiere de la violencia ni hace uso de ella de manera sistemática. Tanto el hecho de prohibirse por mandato constitucional la reelección a los cargos públicos de elección popular como la sucesión en la presidencia nacional cada seis años conllevan, según este enfoque, una renovación en los puestos de mando que alejan al sistema del autoritarismo, lo mismo que de una desviación desmedida hacia los extremos.

Casos como la represión feroz desatada en México en contra del movimiento estudiantil de 1968, los asesinatos estudiantiles de 1971, la matanza de Acteal en diciembre de 1997, la de Aguas Blancas en 1998 o el asesinato y desaparición de líderes obreros, campesinos e indígenas, de opositores políticos que luchan dentro de la legalidad siguen hasta hoy día, ${ }^{3}$ pero se distorsionan ante la opinión pública. Al mismo tiempo se desvía la atención de las denuncias por corrupción, que según numerosas personas y opiniones es uno de los problemas más graves del sistema gubernamental mexicano y brasileño, incluidos los de Vicente Fox Quesada y Luiz Inácio Lula da Silva. Unos y otros se minimizan como si no fueran actos políticos, como si fuesen circunstanciales. Si algunas veces se emplean los cuerpos policiacos o militares es porque son necesarios quizás por la coyuntura, pero que nunca dejan de ser considerados como hechos aislados, hasta lamen-

\footnotetext{
${ }^{3}$ Sólo como parámetro, se han señalado casi 300 asesinatos de personas afiliadas a la oposición mexicana entre 1988 y 1994, a los que habría que sumar la gente sin partido y que sin ser opositores al régimen han muerto por la represión en el campo; sin duda, también suman varias centenas.
} 
tables, de los que pueden ser responsables un individuo o una institución, pero no el sistema en su conjunto.

Tanto en México como en Brasil, la violencia en contra de los colonos y menores en las grandes ciudades, la que se aplica en contra de campesinos e indígenas día a día, si llega a captar la atención de algún noticiero radial, televisivo o periodístico se presenta como operativos o golpes policiacos y militares en contra de la delincuencia común o del narcotráfico y, por lo tanto, algo que el común ciudadano debe aplaudir. En estos casos, la eficiencia judicial es impresionante. Denuncias de violencia en contra de mujeres, menores e indios rara vez aparecen en la prensa nacional más crítica o bien se publican en las secciones de nota roja. Cuando existen pruebas contundentes, no se acusa de frente a instituciones como el ejército. Si no queda alternativa, se utiliza el eufemismo: "según la fuente, hombres vestidos con uniforme militar..."
Este velo sobre la información, esta alianza y control de los medios de comunicación hacen posible que los gobiernos de los dos países repriman, por un lado, y celebren la libertad de prensa, por el otro. Por lo mismo, en el exterior los gobernantes pueden adoptar una postura que defiende la autodeterminación y la democracia, cuyas reglas deben aplicarse a otros pueblos pero no al país que representan. En el caso de México, su imagen democrática (que se ha visto empañada por la rebelión zapatista de Chiapas) ha sido tan publicitada que, con base en la premisa cierta acerca de la continuidad del sistema gubernamental y ahora de la alternancia pacífica, México se cataloga como un país estable según diversos parámetros, casi todos indicadores de la macroeconomía, que no se reflejan en los bolsillos o estómagos de las personas concretas. Además, debido al crecimiento económico que tuvieron México y Brasil en el tercer cuarto del siglo XX, son

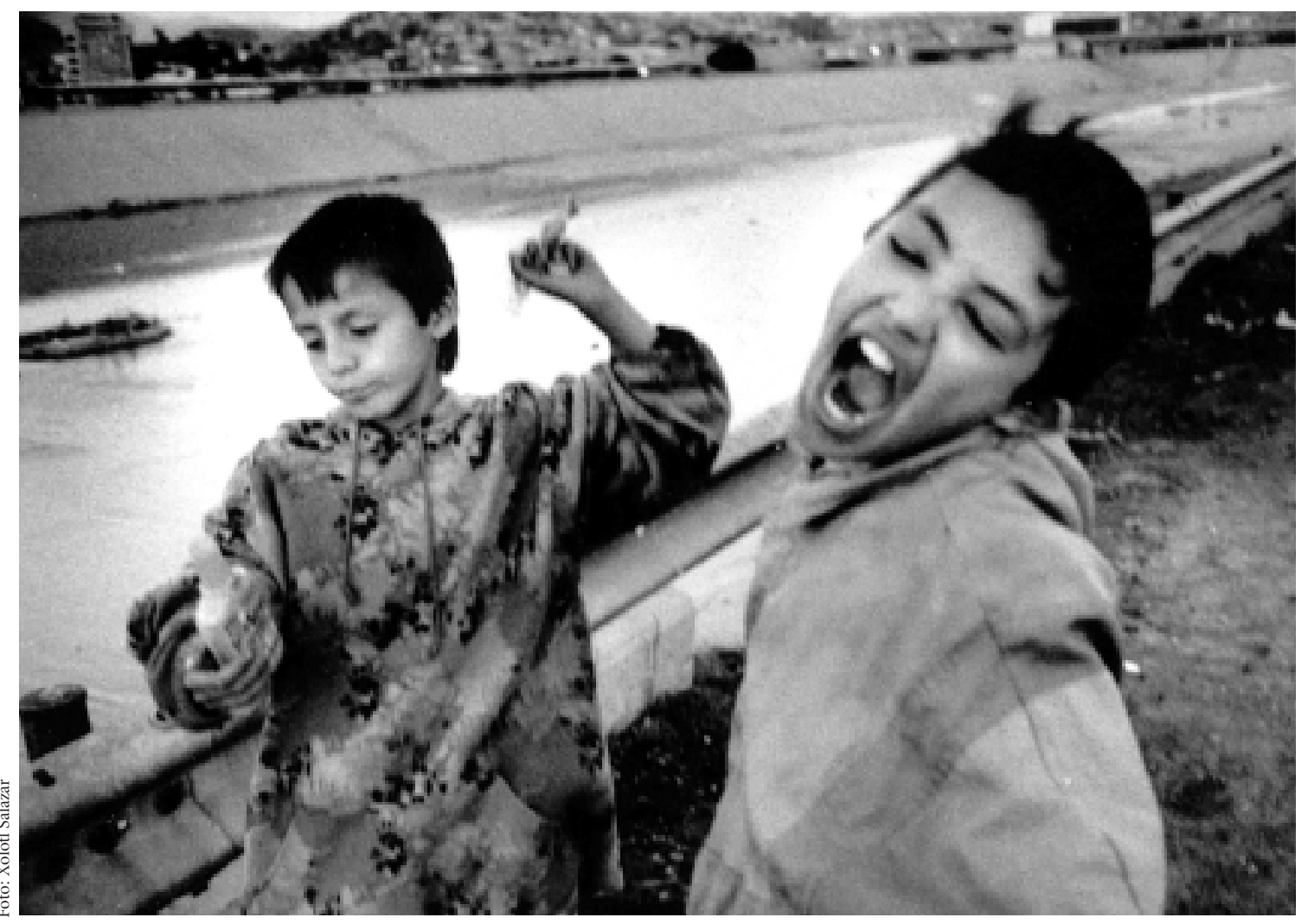

Daniel y Beto en El Bordo; Tijuana, 2000. 
tomados como ejemplo entre los especialistas para otros países subdesarrollados para enfrentar la crisis económica que afecta en diferentes grados a Latinoamérica.

¿Cuánto de cierto hay en estas aseveraciones? Lo primero que hay que decir es que el bienestar aparejado al crecimiento económico sostenido de más del 5\% anual durante varios años seguidos — calificado en ambos países como "milagro" — no benefició a la población rural de bajos y medios ingresos sino al sector agroexportador. Además de sus sectores industriales, en Brasil los beneficiarios fueron los productores de soya, jugos de frutas, ganado y aves para el mercado mundial (Perz, 2000: 8) mientras que en México fueron los agricultores de trigo y hortalizas, principalmente destinados al mercado estadounidense.

Aunque se aplica a todas las zonas indígenas del territorio nacional, lo ocurrido en la Huasteca refleja de cerca las relaciones violentas y represivas que imponen las clases dominantes de México, a través del Estado, a las comunidades y grupos subordinados desde la conquista, pasando por la Independencia, la Reforma, la Revolución y los gobiernos neoliberales.

Como en el resto de América, la llegada de los europeos a la Huasteca estuvo ligada a un proceso que desencadenó a través de la violencia un flujo de riquezas, productos y trabajo humano hacia Europa (Warman, 1988: 13), en el que las comunidades indias fueron las explotadas. En la Huasteca se traficó con esclavos, mantas de algodón, pescado y productos artesanales. Ya que carecía de metales preciosos, fueron otros los factores que la hicieron atractiva a los ojos de los europeos, como el hecho de ser una zona de alta densidad demográfica, contar con puertos de enlace con las Antillas y por consiguiente, con Europa, y tener un clima que propició la rápida expansión de la caña de azúcar y de la ganadería. Con todo, al inicio de la etapa colonial fue la fuerza de trabajo la que se constituyó en su mayor riqueza, por lo que la despoblación fue más rápida que en otras regiones. De poco más de un millón de habitantes que existían antes de 1519, medio siglo más tarde habían desaparecido al menos las cuatro quintas partes.

Entre el inicio de la Colonia, 1521, y la etapa independiente, 1810 , los huastecos se rebelaron en diversas ocasiones y de las mismas se sabe poco. En 1523, 1525 y 1527 se registran las primeras guerras, cuando los huastecos se rebelaron en contra de la imposición de tributos y encomiendas que favorecían a los españoles. Así mismo, se sublevaron por la saca de esclavos que se incrementó sobremanera cuando Cortés repartió las primeras encomiendas y, luego, cuando Nuño de Guzmán fue gobernador de la provincia de Pánuco entre 1527 y 1528. A partir de entonces, hasta la época independiente, información fragmentaria nos habla de acciones varias en contra de la colonización que incluían hechos pacíficos (migración para no pagar tributos, no tener hijos, continuar los rituales religiosos ocultos) y luchas armadas como motines, revueltas, rebeliones, que ni siquiera disminuyeron al terminar la lucha de Independencia. Entre los pueblos de la Huasteca no todas las comunidades perdieron sus tierras por la lucha que opusieron y no en todas se repartió el fundo legal en lotes individuales como era la intención del Estado decimonónico. Todo esto se dirimió a través de la lucha armada pues en ese mismo periodo, 1810-1910, hubo 52 rebeliones de diferente magnitud y alcances.

Terminada la Revolución en 1921, en casi todo el territorio rural mexicano los caudillos revolucionarios regionales y sus descendientes se adueñaron de las instituciones surgidas de la revolución y del territorio, de manera que concentraron tierras y poder político. En este panorama casi general, los caciques de la Huasteca descollaron por su ferocidad, su intransigencia y su primitivismo. Ferocidad en contra de los indígenas y las comunidades que se destacaron o destacan por su combatividad; intransigencia hacia cualquier cambio en las formas de control político o de mejoría en las condiciones de vida de las comunidades; primitivismo por su cerrazón al diálogo y, en lo económico, por su negativa rotunda a introducir mejoras en la explotación agropecuaria, actividad a la que todos ellos se han dedicado.

Esta situación empezó a cambiar a fines de la década de 1970, cuando nacieron organizaciones campesinas independientes, construidas y dirigidas por los propios nahuas, teenek, otomíes, etc. Aunque no se pueden agrupar bajo la misma bandera ni signo, cada una de ellas ha hecho su aportación a la lucha campesina-indígena de la Huasteca. Las más combativas son también las que han pagado una cuota más alta de sangre, presos y acoso gubernamental. 
Baste decir que en el transcurso de 1976 a 1990, debido a la acción de todas ellas que por desgracia no ha sido conjunta, a cambio de un medio millar de muertos, cientos de detenidos, secuestrados y encarcelados según las propias fuentes oficiales, se recuperaron alrededor de 20000 hectáreas en toda la región. Para las dimensiones del Brasil, donde uno de los propios líderes del MST, Joao Pedro Stedile, propuso que el límite de la propiedad privada se estableciera en mil hectáreas (Pereira, 2003: 11) ese territorio es pequeño. Pero hay que pensar que México agotó su frontera agrícola, que la Huasteca es una región rural con una densidad promedio cercana a los 100 habitantes por kilómetro cuadrado y tierras fértiles con un índice de agostadero de una hectárea por cabeza de ganado. Todo esto, en una región en donde las actividades agropecuarias dependen de las lluvias.

Esta recuperación de tierras obligó a los latifundistas a invertir sus capitales en otros renglones económicos. El Estado los recompensó con creces después de que muchas comunidades ya habían tomado posesión de la tierra: perdieron los ranchos pero incrementaron de esa manera su capital, que enseguida transfirieron al sector de los servicios y del comercio o a las mismas actividades agropecuarias en otros estados de la República.

En Brasil, con el gobierno de Fernando Henrique Cardoso, que repartió más tierra que sus antecesores, pasó algo semejante: "De esta manera, la compensación pagada a los terratenientes es a menudo mucho más alta que el valor estimado de la tierra según lo calcula el gobierno" (Martins, en Pereira, 2003: 15).

En la Huasteca, los momentos más críticos de la represión coincidieron con la etapa en que se recuperaron más tierras (1976-1983); sin embargo, tanto antes como después se pueden documentar y probar hechos violentos continuos que dan idea de su constancia y frecuencia aunque se afirme por voceros oficiales que hay estabilidad social. La tierra como generadora de riqueza, como medio de producción, es un elemento importante de la lucha pero ni ahora ni históricamente su despojo ha sido el motivo único, aunque sí lo ha sido en los movimientos campesinos.

En Brasil, la colonización portuguesa giró al principio en torno a las plantaciones de azúcar en el litoral, lo que abarató y generalizó su consumo mundial; luego, en torno a la ganadería y la extracción de oro en el interior y después, al café, a partir del siglo XIX. La ocupación de las tierras por parte de los portugueses se dio a lo largo de la costa atlántica y sólo cuando se encontró oro en el interior del país hubo intentos serios para establecer poblados permanentes tierra adentro. Ni en el caso de Brasil ni en el de México se puede hablar de un proceso de colonización uniforme; tampoco fue semejante en todo el territorio, aunque para la población indígena tuviera a fin de cuentas resultados parecidos.

Los cuellos de botella en la producción agropecuaria colonial brasileña se presentaban por la escasez de la mano de obra y no por la extensión territorial que requerían las plantaciones (Furtado, 1974: 59, 117). Por lo tanto, antes de que se fundaran colonias estables en el interior, ya varios grupos indios habían sido esclavizados por expediciones de blancos que surtían a las plantaciones con mano de obra indígena. Así, "la primera actividad comercial a la cual se dedicaron los colonos [portugueses] fue la caza del indio" (Furtado, 1974: 63). El té en las mesas europeas se endulzó con la sangre, el dolor y el sufrimiento esclavo de indios y después de negros traídos de África. A diferencia de México, donde la ocupación europea se centraba primero alrededor de los centros urbanos donde se concentraba la población y se podía extraer tributo y, luego, de los enclaves mineros, la esclavitud en el Brasil ocurrió "en los lugares en que los finqueros eran los jefes políticos [...] los señores de la sociedad brasileña durante el periodo colonial y el Imperio" (Freyre, 1978: 59). Por otro lado, los grupos indios que en un primer momento lograron escapar del colonizador occidental, lo mismo que en México, se vieron luego despojados de su territorio, muchos de ellos sirvieron como peones en los ranchos que pasaron a ocupar sus tierras ancestrales (Wagley y Harris, 1964: 32).

En la actualidad, al revisar de manera general las denuncias y los análisis sociales sobre la violencia en Brasil, impresionan las similitudes del proceso, lo mismo que sus causas y consecuencias, con lo que pasa en México, y tal parece que, aparte de lo que acontece por cuestiones del narcotráfico, lo mismo sucede en el resto del continente. Impresiona, por ejemplo, que en el país más grande de 


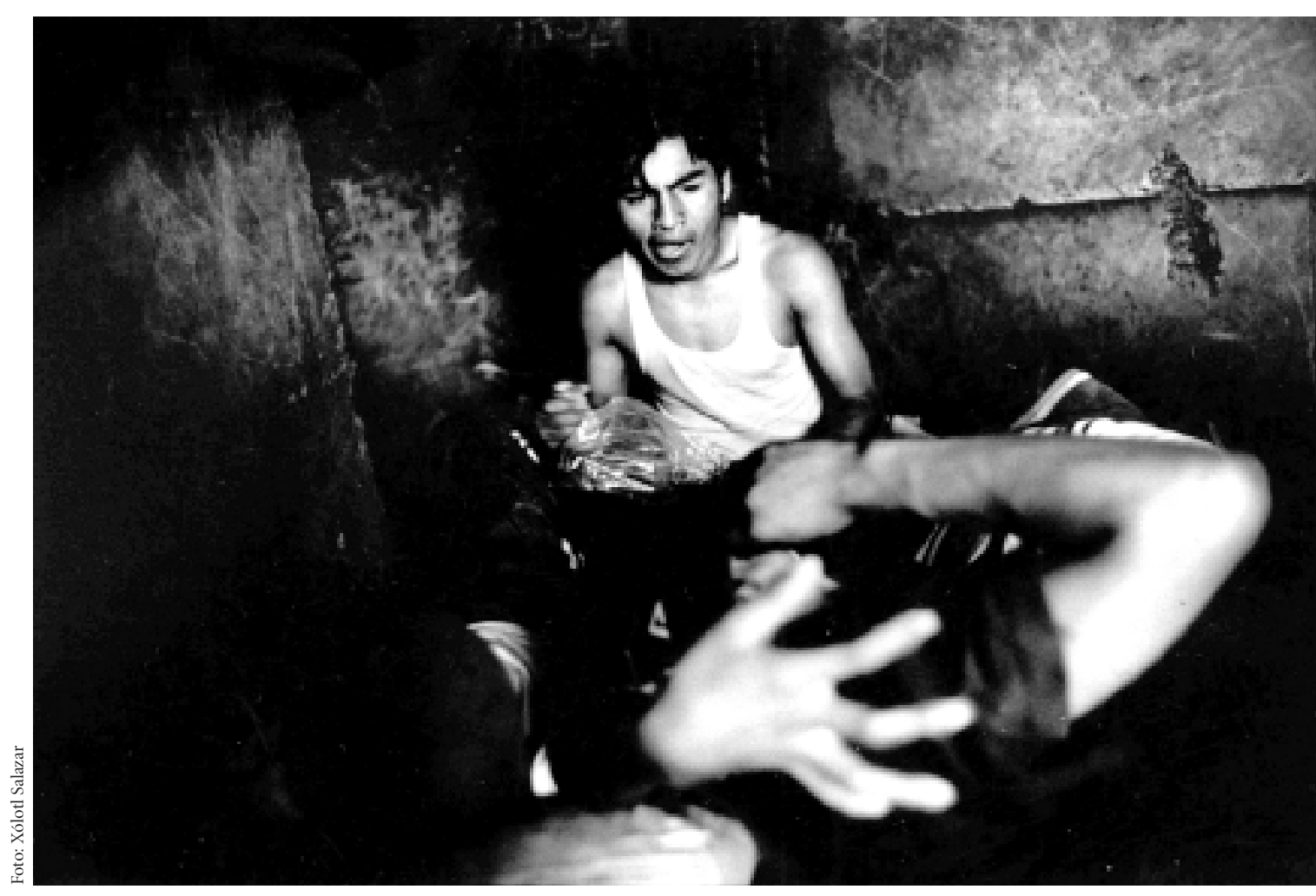

El Oaxaco en un agujero en El Bordo; Tijuana, 2000.

América Latina, con alrededor de 8.5 millones de kilómetros cuadrados y unos 180 millones de habitantes, la violencia en el medio rural esté ligada de manera primordial a la propiedad de la tierra, al despojo agrario y a la explotación del trabajo ajeno. De igual manera, es un hecho que la represión virulenta de los gobiernos militares en contra de la sociedad brasileña no se puede entender si no está relacionada a un proyecto económico específico; en este caso, en estrecha relación con el llamado milagro brasileño, que sometió la soberanía nacional al capital extranjero (Senese, en Weil et al., s.f.: 18).

Más recientemente, aunque sus gobernantes pretenden por diversos medios presentarlo como un país democrático y pacífico, llama la atención el que la violencia forme parte de la vida cotidiana de los trabajadores rurales del Brasil, de norte a sur del país (IBASE, 1985: 8-9). Es decir, la violencia es un problema nacional (Sigaud en Velho et al., 1987: 6). Como también pasa en México, no son los te- rratenientes en persona, aunque a veces lo hagan, quienes ejercen la agresión, sino que contratan, arman y pagan a pistoleros, con frecuencia reclutados entre los mismos campesinos e indígenas, con quienes forman cuerpos armados especializados en la represión. Es común en ambos países que tanto represores como reprimidos guarden lazos de parentesco. En México los llaman guardias blancas, columnas volantes, pistoleros; mientras que en Brasil se les nombra cabras, capangas, jagunços, bandos armados o milicias privadas (A. García Jr., 1988: 14; IBASE, 1985: 8; Sigaud en Velho et al., 1987: 6). A fines del siglo XX, matar a un líder campesino costaba alrededor de 40 dólares en Brasil (Sallinger-McBride y Roberts, 1998) y unos 100 dólares en México.

En el mismo tenor, la impunidad de los asesinos y de los represores es casi absoluta (Fajardo, 1988: 5) cuando se trata de castigar los crímenes en contra de indios o campesinos. Por lo general, ni en México ni en Brasil se castiga 
a los terratenientes, aun cuando haya evidencias irrefutables de sus crímenes. Ni a la mano armada ni a la cabeza intelectual las alcanza la justicia; ésta no se hizo para los pobres. Algunos casos de castigo son excepcionales y sólo se logran a través de la presión internacional. La violencia no la desencadenan las personas pobres, sino grupos que ocupan diferentes lugares en la jerarquía social (Velho et al., 1987: 3). Otra similitud es la ferocidad de la represión que se desata cuando una de las víctimas, individual o colectivamente, se hace justicia por su propia mano. Se usa el ejército, se reprime a la población civil, se les atrapa y acusa de delincuentes del orden común, se les juzga y se les castiga con rigor excesivo sin respetar las mínimas garantías individuales.

Según el enfoque de este escrito, el proceso de la violencia en el medio rural no se desata de por sí, sino que está ligado al proceso económico que acompaña a la expansión o irrupción del capitalismo en determinadas áreas de la economía. Tanto en el caso de Brasil como en el de México, la violencia actual en el campo se liga a la expansión de la agricultura tipo revolución verde, que consigue en ambos países un apoyo irrestricto del Estado sobre cualquier otra forma de producción agrícola, y a la falsa lucha en contra del narcotráfico. Según uno de los estudiosos brasileños, la violencia en Brasil tiene como una de las causas principales la pobreza, la miseria y la desigualdad en la distribución de la renta (Velho et al., 1987: 3). Tan sólo para poner un ejemplo, en 1995, en Brasil, 1\% de la población poseía $45 \%$ de la tierra. En otras palabras, lo mismo que en México, la violencia es condición característica del Estado brasileño no por su forma de gobernar, sino para mantener las jerarquías y la desigualdad sociales, mismas que en el campo tienen como base la propiedad agraria, el monopolio del comercio y la explotación de los recursos naturales.

\section{REFLEXIONES FINALES}

1. A pesar de las diferencias históricas entre México y Brasil, a pesar de haber pasado ambos países por procesos de colonialismo motivados por el despojo de diferentes

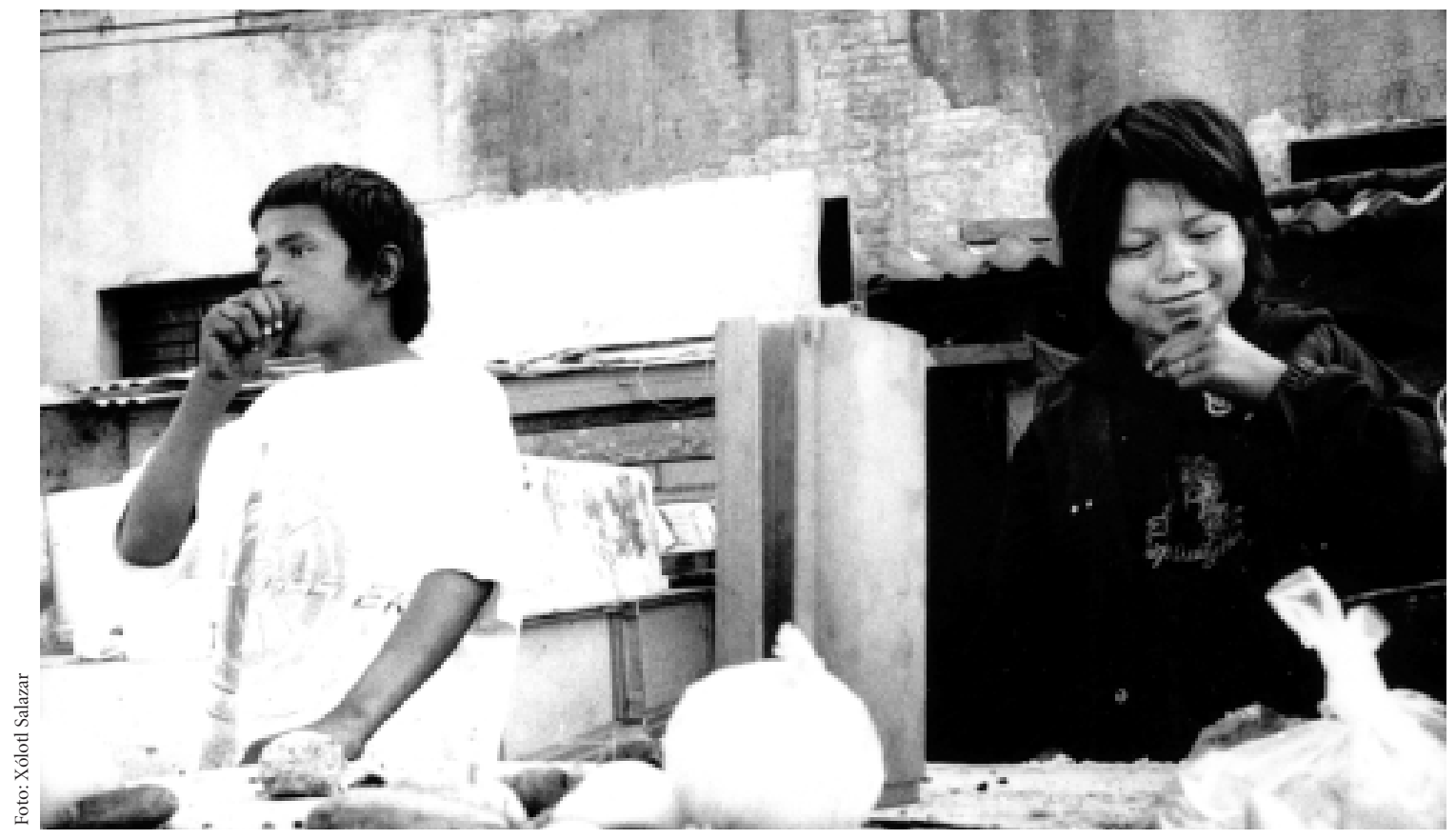

Vías del tren; Tlatelolco, México, D. F., 1999. 
tipos de recursos, a pesar de sus divergencias coloniales, biogeográficas, lingüísticas, demográficas y tecnológicas, ninguno de sus gobiernos se puede calificar de respetuoso de los derechos humanos de sus ciudadanos; menos aún de sus pueblos indios. Las evidencias pasadas y presentes de la represión que ejercen o han ejercido sus clases dominantes en contra de los trabajadores y los grupos minoritarios muestran que mientras que sus proyectos económicos estén supeditados a la explotación de la mano de obra y a la expoliación de los recursos naturales, no habrá ámbito para terminar con la desigualdad y la injusticia social que impera dentro de ellos.

2. Sin duda, la mayoría de la población mundial quiere vivir y trabajar en paz; este hecho no necesita comprobación estadística, sino sensibilidad para percibir la vida cotidiana del común de los vecinos. A pesar de las encuestas que muestran lo contrario, es imposible aceptar que $85 \%$ de la población pueda estar de acuerdo con una guerra, cualquiera que ésta sea. Y aun cuando fuera cierto, aun con la anuencia de la ONU y la aceptación de su Consejo de Seguridad, ningún motivo justifica el empleo de la violencia en contra de un país, grupo social, organización política o persona a menos que se trate de la defensa legítima ante la represión. En pocas palabras, ninguna razón existe para que se declare que una guerra es justa o legal, no importa cuánto se publicite o se manipule la información. Si el Consejo de Seguridad o la ONU aprueban tales barbaries, ello no es señal de que se trate de guerras justas, sino que es un testimonio contundente de su fracaso en conservar el espíritu con que fueron creados esos organismos y de que la sociedad mundial debe diseñar nuevos mecanismos, si no para vivir la paz, que parece que todavía nos queda grande, al menos para erradicar la violencia.

3. Plantear y analizar los componentes de la expoliación que ejerce la clase gobernante sobre campesinos, indígenas, obreros, mujeres y menores, sin embargo, no es suficiente en términos de una explicación más profunda del fenómeno ni de las acciones que se contraponen para anular o aminorar el saqueo. A su separación metodológica en las fases de explotación, opresión y re- presión se debe añadir su relación analítica con la vida cotidiana y los recursos con los que cuenta el grupo. En este sentido, aunque sin duda influye la capacidad de sustentación del medio ambiente, se concluye que las causas profundas de la violencia radican en el orden social: 1) la desigualdad extrema en la producción y el reparto de la riqueza social que genera el conjunto humano en que unos cuantos concentran la mayor parte de beneficios, 2) las formas de acceso y propiedad de los recursos naturales, tanto vitales como estratégicos, 3) la propiedad de los medios de producción y del capital, y 4) las crisis regionales.

4. Durante la segunda mitad del siglo XX, la población de México y Brasil se convirtió de predominantemente rural en urbana. Dicha transformación se debió a que con la intrusión del capitalismo en el sector rural disminuyeron las posibilidades de los productores rurales medianos y pequeños y no porque haya habido un desarrollo tecnológico tendiente a aliviar la pobreza ni las enormes diferencias entre los distintos sectores y clases de cada nación. El éxodo rural se debe a la cancelación de oportunidades para los pobres en el campo y a que en la política económica los pobres se consideran desechables. Se ambicionan sus tierras y recursos naturales, al menos los mejores, pero no sus organizaciones ni su forma de producción. De hecho, los migrantes rurales ocupan los cinturones de miseria en las ciudades mexicanas (ciudades perdidas) y brasileñas (fabelas) y sólo se les contrata en empleos de muy baja remuneración, calificación y salario. Estos barrios carecen de servicios, seguridad y empleos y, en cambio, abundan en delincuencia, tristeza y abandono. En el campo no se apoya a los pequeños productores, categoría donde se ubican los pueblos indígenas, sino a los grandes empresarios agrícolas y consorcios que producen para el mercado internacional. Las ayudas que reciben las comunidades campesinas e indígenas provienen de su propia iniciativa, de una o varias iglesias y, recién, de organizaciones no gubernamentales o fundaciones internacionales.

5. Vale la pena regresar a una pregunta inicial, o sea, la de si todos los procesos violentos responden a las mismas razones. La respuesta depende del enfoque. Si nos ubi- 


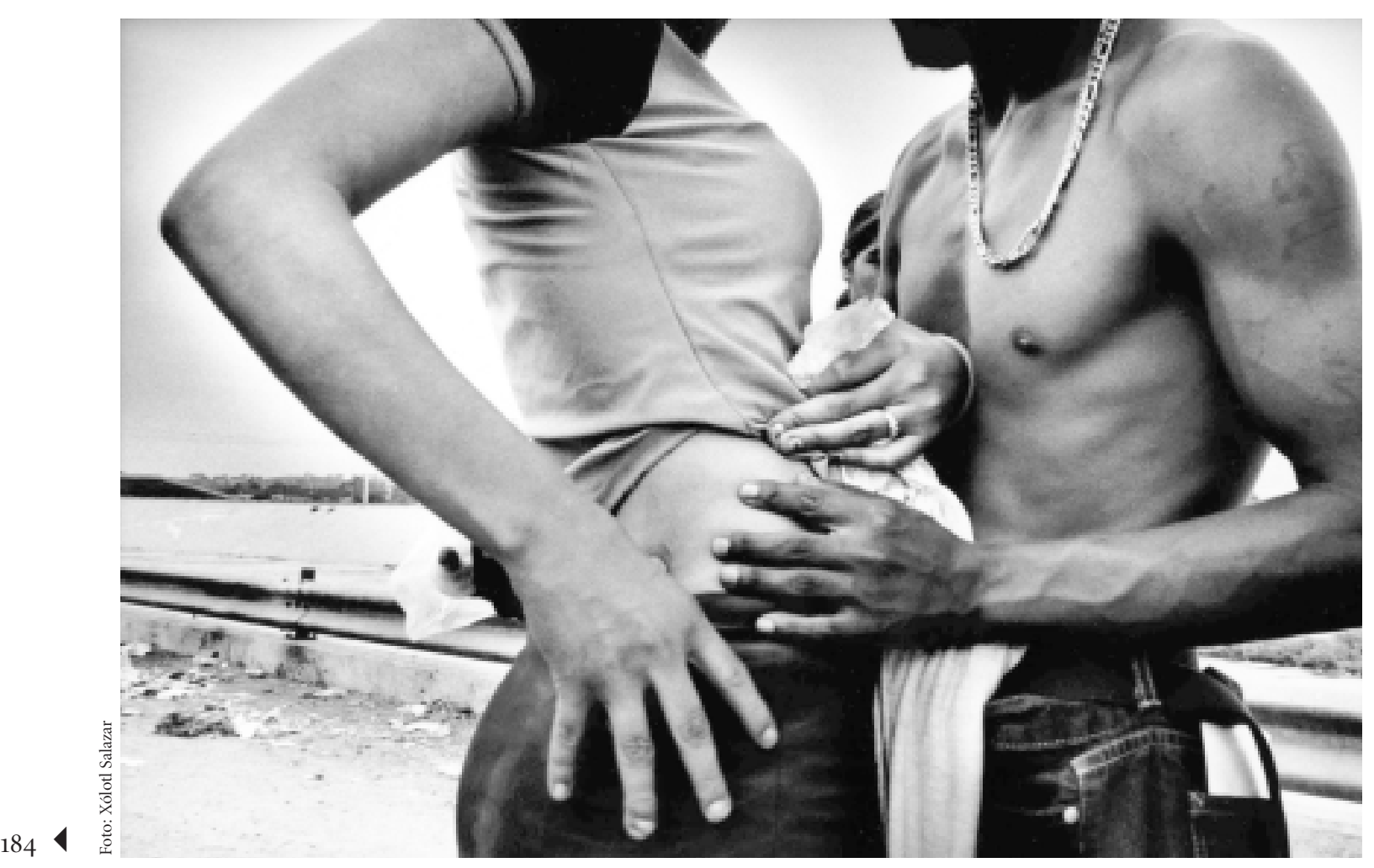

Tijuana, 2000

camos del lado de la víctima, si analizamos nada más el sentido o finalidad de la violencia, la respuesta es positiva. Si nos percatamos de las formas que adquiere en cada proceso, si nos detenemos en los mecanismos sociales de que echa mano cada grupo dominador, es obvio que la respuesta es negativa. No es lo mismo someter a un grupo a través del asesinato generalizado que hacerlo a través del machismo; ni son lo mismo las guerras mundiales con potencial nuclear que las que acontecen entre grupos sin armas de fuego. Como apunta Sussekind (en Velho et al., 1987: 10): "La violencia no consiste en una misma desgracia igualmente impuesta a todas las víctimas por el mismo tipo de autor." Sin embargo, cuando se ha empleado en contra de los grupos indios, las medidas que se utilizan, así como muchas de sus manifestaciones, son semejantes o muy parecidas, como si estuvieran sacadas del mismo manual.
6. Hay que insistir en que la represión y la violencia, ya sea que se den individual o colectivamente, implican un acto consciente, una especificidad sobre el blanco al que se dirigen, y de otra inteligencia que resiste. Por lo mismo, al menos desde este enfoque, no es posible hablar de violencia estructural, violencia institucional, violencia indirecta y menos de estructuras violentas. Lo que existe son instituciones sociales y grupos especializados a través de los cuales se ejerce la violencia y un grupo o clase que controla tales instancias. Estas incluyen el Estado, las bandas paramilitares y los cuerpos armados, en defensa de intereses bien definidos ya sean individuales, familiares o de clase. Lo anterior es evidente en el caso de México y Brasil.

7. Las ideas centrales y la mayor parte del contenido de este artículo se elaboraron hace unos diez años. Desde entonces, ha habido cambios en los sistemas políticos de México y Brasil señalados a lo largo de la exposición. 
Encabezada por Vicente Fox Quesada y Luiz Inácio Lula da Silva, la alternancia gubernamental en los dos países implicó el triunfo de partidos de oposición; en México, de un partido de derecha, el PAN, y en Brasil, del PT, de centro izquierda. Esta alternancia, cabe preguntarse, ¿cambió la situación de la violencia rural? La respuesta depende de cómo se mida. Si se hace en términos de asesinatos es evidente que ha disminuido con respecto a los regímenes pasados. Pero si se evalúa en cuanto a las condiciones que imperan entre campesinos e indígenas la respuesta es negativa. Quizás en Brasil hayan mejorado algo con el actual gobierno, aunque la información disponible no apunta en esa dirección, sino a la continuidad de asesinatos y complicidades con los latifundistas según afirman organizaciones y analistas varios (http://prod.brasil.indymedia.org). Hay que decir, sin embargo, que es demasiado pronto para emprender un diagnóstico del gobierno del presidente Lula, pero en México la situación de pobreza se ha profundizado y se ha hecho más extensa.

8. Por lo visto, para terminar con la violencia en el campo no es suficiente el reparto de la tierra. Tanto en México como en Brasil se hizo un reparto considerable de tierras entre los campesinos, pero este hecho, por sí solo, no erradicó la violencia ni fue suficiente para sacar a los campesinos de su ancestral abandono. Tampoco los programas asistenciales han logrado paliar la pobreza del campo. Es decir, según el enfoque aquí expuesto, es necesario un cambio de orientación en las políticas económicas nacionales que contemplen el apoyo decidido a los pequeños y medianos productores rurales. Estas políticas debieran incluir la construcción de infraestructura productiva, la construcción de cooperativas y organizaciones autónomas campesinas, así como tender redes para la compra de los insumos necesarios y para la comercialización de los productos campesinos. Como muestra el ejemplo del movimiento de los trabajadores sin tierra de Brasil, la educación y la capacitación de cuadros es también una condición para lograr un desarrollo rural sostenido y autónomo. Por ahora, ninguna de las dos naciones camina en ese sentido sino que, por el contrario, los logros de las organizaciones campesinas se han dado a pesar de las políticas económicas nacionales, con el apoyo de otros sectores de la sociedad.

9. En suma, la alternancia de gobernantes sin un cambio de políticas económicas no podrá sacar de la pobreza a los pequeños productores rurales ni detendrá la migración hacia los enclaves urbanos. En consecuencia, no habrá forma de romper ese círculo vicioso de marginación urbana, delito e inseguridad mientras no se atienda la situación de los pobladores rurales, para con ello detener la migración y el abandono del campo.

\section{Bibliografía}

Amara, Guiseppe, 1976, La violencia en la historia, Programa Nacional de Formación de Enseñanza Superior (ANUIES), México.

Arante, José Montero Filho, María Bernadete Ramos Flores, Víctor Antonio Peluso Junior, Rafael José de Menezes Bastos, Valdir Martins, Mauro José Machado, 1990, Farra do boi. Introduçâo ao Debate, IOESC, Florianópolis.

Barreira, Julio, 1978, Violencia política en América Latina, Siglo XXI, México.

Beltrán del Río, H., 1991, "Tres años de comicios locales: nuevas leyes, vieja violencia”, Proceso, núm. 771, pp. 2325, México.

Bonin, Ana María Aimoré, Ángela Duarte Damasceno Ferreira, Cecilia Vieira Helm, Horacio Martins de Cavalho, Joao Carlos Torrens y Marcia Scholz de Andrade Kersten, 1987, Movimientos sociais no campo, Criar-Ed. da Universidade Federal do Paraná, Curitiba.

Calderón, Fernando, y Elizabeth Jelin, 1987, "Clases sociais e movimientos sociais na America Latina. Perspectivas e realidades", Revista Brasileira de Ciências Sociais, Associação Nacional de Pos-graduação e Pesquisas em Ciências Sociais (ANPOCS), vol. 2, núm. 5, pp. 67-85, São Paulo.

Cardoso, Ruth Correa leite, 1987, "Movimientos sociais na America Latina", Revista Brasileira de Ciências Sociais, ANPOCS, vol. 1, núm. 3, pp. 27-37, São Paulo.

Córdova, Arnaldo, 1984, La formación del poder politico en México, Era, México.

Chagnon, Napoleón A., 1988, "Life Histories, Blood Revenge, and Warfare in a Tribal Population", Science, núm. 239, pp. 985-992.

Darcy de Oliveira, Miguel, Leila Linhares Barsted y Rosiska Darcy de Oliveira, 1985, Você e a violência. Guia práctico para se defender da violência urbana e dos excessos da polícia, Ordem Dos Advogados do Brasil (OAB)-Instituto Ação Cultural (IDAC)-Vozes, Río de Janeiro. 
Donoso Pareja, Miguel, 1973, La violencia en el Ecuador, Diógenes, México.

Fajardo, Elías, 1988, Em Julgamento. A Violência no Campo (Relato das mortes analisadas pelo Tribunal Nacional dos Crimes do Latifúndio), Vozes-Instituto Apoio Jurídico Popular-FASE, Petrópolis.

Feder, Ernest, 1978, Violencia y despojo del campesino: latifundismo y explotación, Siglo XXI, México.

Ferreyra Moyano, Horacio, 1972, Cerebro y agresión, Ediciones Nueva Visión, Buenos Aires.

Freyre, Gilberto, 1978 (1945), Interpretación del Brasil, FCE, México.

Furtado, Celso, 1974, Formación económica del Brasil, FCE, México.

García Jr., Afranio, 1988, "Libertos e sujeitos: sobre a transição para trabalhadores livres do Nordeste", Revista Brasileira de Ciências Sociais, ANPOCS, vol. 3, núm. 7, pp. 5-41, São Paulo.

Garver, Newton, s.f., “QQué es la violencia”?, Archivo CIDOC, documento 34, pp. 159, Nueva York.

Genovés, Santiago, 1977, Violencia. Una visión general, UNAM, México.

Hirschman, Albert, 1987, "A economía política do desenvolvimento latino-americano”, Revista Brasileira de Ciências Sociais, ANPOCS, vol. 1, núm. 3, pp. 51-72, São Paulo.

Houtzager, Peter P., 2000, "Social Movements Amidst Democratic Transitions; Lessons from the Brazilian Countryside", The Journal of Development Studies, vol. 36, núm. 5, pp. 59-88, Londres.

Huizer, Gerrit, 1974, El potencial revolucionario del campesino en América Latina, Siglo XXI, México.

Instituto Brasileiro de Análisis Sociais e Economicos (IBASE), 1985, Violência no campo, Vozes, Petrópolis.

Luxemburgo, Rosa, 1967, La acumulación del capital, Grijalbo, México.

Maffesoli, Michel, 1987, Dinâmica da violência, Biblioteca Vértice, São Paulo.

McNeil, Elton B., 1975, La naturaleza del conflicto humano, FCE, México.

Michaud, Yves, 1989, A violência, Atica, São Paulo.

Oliven, Ruben George, 1989, Violência e cultura no Brasil, Vozes, Petrópolis.

Ortiz, Orlando, 1971, La violencia en México, pról. y sel. de Orlando Ortíz, Diógenes, México.

Palafox Vargas, Miguel, 1985, Violencia, droga y sexo entre los huicholes, INAH, México.

Pereira, Anthony, 2003, "Brazil's Agrarian Reform: Democratic Innovation or Oligarchic Exclusion Redux?, Latin American Politics and Society, vol. 45, núm. 2, pp. 41-III, Coral Gables.
Perz, Stepehn G., 2000, "The Rural Exodus in the Context of Economic Crisis, Globalization and Reform in Brazil", The International Migration Review, vol. 34, núm. 3, pp. 842-881, Nueva York.

Romanucci-Ross, Lola, 1973, Conflict, Violence and Morality in a Mexican Village, National Press Book, Palo Alto, California.

Ruvalcaba Mercado, Jesús, 2002, "Explotation économique, discrimination et violence dans la Huasteca”, en Annamária Lammel y Jesús Ruvalcaba Mercado (eds.), Adaptation, violence et révolte au Mexique, L'Harmattan (Recherches Amériques Latines), París, pp. 223-246.

Sallinger-McBride, Jan y Lia K. Roberts, 1998, "Conflict Between the Landed and the Landless in Brazil", International Journal on World Peace, vol. 15, núm. 4, pp. 6190, Nueva York.

Santos, Silvio Coelho Dos, 1975, Educação e sociedades tribais, Editora Movimento, Porto Alegre.

—_, 1987, Indios e brancos no sul do Brasil. A dramática experiência dos Xokleg, Editora Movemento, Porto Alegre.

Sorel, Georges, 1970, Reflections on Violence, Collier MacMillan, Londres.

Velázquez Rivera, Luis, 1985, Bamba violenta, Océano, México.

Velho, Gilberto, Ruth Correa Leite Cardoso, Maria Luiza Heilborn, Luiz Mott, Maria Manuela Carneiro da Cunha, Tereza Cristina Nascimento de Araujo, Alba Zaluar, Julita Lemgruber y Augusto Thompson, 1987, Ciência Hoje, vol. 5, núm. 28, suplemento especial sobre la violencia, São Paulo.

Veltmeyer, Henry y James Petras, 2002, “The Social Dynamics of Brazil's Rural Landless Workers' Movement: Ten Hypotheses on Successful Leadership", Revue Canadienne de Sociologie et d'anthropologie, vol. 39, núm. 1, pp. 79-99, Toronto.

Viqueira, Carmen y Ángel Palerm, 1954, "Alcoholismo, brujería y homicidio en dos comunidades rurales de México", América Indígena, vol. XIV, núm. 1, pp. 7-36, México.

Wagley, Charles y Marvin Harris, 1964, Minorities in the New World, Columbia University Press, Nueva York.

Warman, Arturo, 1988, La historia de un bastardo. Maíz y capitalismo, FCE, México.

- 2003, Los indios mexicanos en el umbral del milenio, FCE, México.

Weil, Jean Louis, Joseph Comblin y Judge Senese, s.f., The Represive State. The Brazilian "National Security Doctri$n e$ " and Latin America, Brazilian Studies-LARU, documentos III, 2, Toronto.

Weil, Simone, 1982, Reflexiones sobre las causas de la libertad $y$ de la opresión social, Premiá, México. 